\title{
PENINGKATAN KUALITAS DAN MUTU PENDIDIKAN DENGAN MENINGKATKAN ADMINISTRASI SARANA DAN PRASARANA
}

\author{
Muhamad Fredi. S \\ Pendidikan Teknik Elektro, Universitas Negeri Padang \\ Setiawan.mf17@gmail.com
}

\begin{abstract}
Dalam usaha peningkatan kualitas dan mutu Pendidikan, disamping usaha peningkatan administrasi lainya seperti peserta didik, pendidik dan tenaga kependidikan, upaya peningkatan pengelolaan sarana dan prasarana sangat penting untuk dilakukan. Karena dengan adanya pengelolaan sarana dan prasarana yang efektif dan efisien pada lembaga pendidikan maka kualias dan mutu suatu lembaga Pendidikan akan akan terpelihara dengan baik. Dalam pengelolaannya, pihak sekolah harus dapat bertanggung jawab terhadap sarana dan prasarana terutama kepala sekolah yang secara langsung menangani sarana dan prasarana tersebut. Dan pihak sekolahpun harus dapat memelihara dan memperhatikan sarana dan prasarana sekolah yang sudah ada. Maka dengan adanya sarana dan prasarana yang memadai di sekolah, maka siswa dapat belajar dengan maksimal dan seefesien mungkin. Artikel ini membahas tentang administrasi sarana dan prasarana dimulai dari pentingnya sarana dan prasarana di Pendidikan, perencanaan sarana dan prasarana, pengadaan sarana dan prasarana, penyaluran sarana dan prasarana, dan pemelihara-an sarana dan prasarana.

Kata Kunci: Pendidikan, Sarana dan prasarana, Efektif dan Efisien.
\end{abstract}

\section{A. PENDAHULUAN}

Pendidikan adalah usaha sadar dan terencana untuk mewujudkan suasana belajar dan proses pembelajaran agar peserta didik secara aktif mengembangkan potensi dirinya untuk memiliki kekuatan spiritual keagamaan, pengendalian diri, kepribadian, kecerdasan, akhlak mulia, serta keterampilan yang diperlukan dirinya, masyarakat, bangsa dan Negara (UU SISDIKNAS No.20 Th.2003) tentang peningkatan mutu merupakan salah satu pilar pembangunan pendidikan di Indonesia. Oleh karena begitu pentingnya pendidikan ini sebagai tempat bagi para peserta didik untuk dapat mengembangkan minat dan bakatnya, maka tentunya untuk dapat mencapai tujuan dari pendidikan itu sendiri yaitu sebagai pembentuk karakter seseorang, maka memerlukan proses pembelajaran yang mempunyai kesingkronisasian dengan kebutuhan peserta didik dan umumnya masyarakat, yang tentunya didukung oleh sarana dan prasarana yang mencukupi sesuai dengan standar keputusan Kementerian Dinas Pendidikan Nasional. Pentingnya sarana dan prasarana untuk menunjang proses pendidikan, diatur oleh Undang- 
Undang Republik Indonesia No 20 tahun 2003 tentang sistem pendidikan Nasional "Setiap satuan pendidikan formal dan non formal menyediakan sarana dan prasarana yang memenuhi yang memenuhi keperluan pendidikan sesuai dengan pertumbuhan dan perkembangan potensi fisik, kecerdasan intelektual, sosial, emosional, dan kewajiban peserta didik' ( Undang-Undang RI Tahun 2003). Juga Peraturan Pemerintah RI No 19 tahun 2005 tentang Standar Nasional Pendidikan Bab VII pasal 42 ayat 1 dan 2 :

- Setiap satuan pendidikan wajib memiliki sarana yang meliputi : perabot, peralatan pendidikan, buku dan sumber belajar lainnya, bahan habis pakai

serta perlengkapan yang diperlukan untuk menunjang proses pembelajaran yang teratur dan berkelanjutan.

- Dari setiap satuan pendidikan meliputi : lahan, ruang kelas, ruang pimpinan, ruang guru, ruang perpustakaan, ruang laboratorium, kantin, tempat berolah raga dan tempat beribadah, tempat bermain, tempat berekreasi, dan ruang tempat lain yang diperlukan untuk menunjang proses pemmbelajaran yang teratur dan berkelanjutan.(PP RI Tahun 2005).

Proses Belajar Mengajar (PBM) atau Kegiatan Belajar Mengajar (KBM) akan semakin sukses bila ditunjang dengan sarana dan prasarana sekolah yang memadai, sehingga pemerintah pun selalu berupaya untuk terus-menerus melengkapi sarana dan prasarana sekolah bagi seluruh jenang tingkatan pendidikan, sehingga kekayaan fisik negara yang berupa sarana dan prasarana sekolah sangat besar menurut Ari H. Gunawan (1996:114).

Pengelolaan sarana dan prasarana sangat penting karena dengan adanya pengelolaan sarana dan prasarana lembaga pendidikan akan terpelihara dan jelas kegunaanya serta meningkatkan kualitas dan mutu suatu Lembaga kependidikan. Dalam pengelolaan pihak sekolah harus dapat bertanggung jawab terhadap sarana dan prasarana terutama kepala sekolah yang langsung menangani sarana dan prasarana tersebut. Dan pihak sekolahpun harus dapat memelihara dan memperhatikan sarana dan prasarana sekolah yang sudah ada. Maka dengan adanya sarana dan prasarana di sekolah siswa dapat belajar dengan maksimal dan seefesien mungkin. Jadi pengelolaan terhadap sarana dan prasarana harus lebih ditekankan lagi dalam lembaga pendidikan seperti sekolah. Dan harus ada yang bertanggung jawab atas pengelolaan sarana dan prasarana tersebut. Dengan pengelolaan sarana dan prasarana yang ada di sekolah kepala sekolah dapat merencanakan dan mendata apa saja sarana dan prasarana yang harus digunakan di sekolah tersebut. Jika semua langkah-langkah pengelolaan telah berjalan dengan baik seperti yang diharapkan maka akan berdampak positif terhadap siswa-siswa dalam proses belajar mengajar dan tercapainya tujuan pendidikan secara efektif dan efisien. Maka penyelenggara pendidikan baik itu pemerintah, kepala sekolah, guru, personil sekolah yang lainnya maupun masyarakat perlu terus berusaha untuk meningkatkan kualitas pendidikan sesuai dengan tuntutan zaman. Dengan sarana dan prasarana yang mencukupi diharapakan outputnya darisana akan mencapai tujuan awal dari sebuah lembaga pendidikan itu sendiri dan meningkatkan kualitas dan mutu suatu Lembaga pendidika. 
Namun dewasa ini, di Indonesia, sarana dan prasarana lembaga Pendidikan sangat kurang dalam pengadaan dan pengelolaanya. Hal ini disebabkan oleh kurangnya anggaran dalam pengadaan sarana dan prasarana terutama di daerah-daerah yang jauh dari ibukota maupun kurang ditekankannya keseriusan dari pihak Lembaga kependidikan dalam mengelola dan memelihara sarana dan prasarana yang ada sehingga ketersediaan sarana dan prasarana menjadi tidak efektif dan efisien dalam penggunaannya. Hal ini sangat disayangkan karena ketersediaan sarana dan prasarana sangat penting bagi sebuah Lembaga kependidikan dan untuk menjadikan sebuah Lembaga Pendidikan yang berkualitas dan bermutu baik harus diiringi dengan pengelolaan sarana dan prasarana yang baik.

\section{B. PEMBAHASAN}

\section{Perencanaan Sarana Dan Prasarana Pendidikan}

Perencanaan sarana dan prasarana pendidikan merupakan suatu proses analisis dan penetapan kebutuhan yang diperlukan dalam proses pembelajaran. Perencanaan dapat dilakukan oleh kepala sekolah, guru kelas dan guru-guru bidang studi dan dibantu oleh staf sarana dan prasarana. Dalam kegiatan perencanaan ada beberapa prosedur yaitu sebagai berikut: 1) mengadakan analisis materi dan alat/media yang dibuthkan; 2) seleksi terhadap alat yang masih dapat dimanfaatkan; 3) mencari dan/atau menetapkan dana; dan 4) menunjuk seseorang yang akan diserahkan untuk mengadakan alat dengan pertimbangan keahlian dan kejuruan.

Selain itu terdapat hal-hal yang harus diperhatikan dalam perencanaan sarana dan prasarana pendidikan adalah sebagai berikut:

- Perencanaan pengadaan barang harus dipandang sebagai bagian integral dari usaha kualitas proses belajar mengajar.

- Perencanaa harus jelas tujuan, jenis, dan bentuk, bahan dan kapan waktu pelaksanaanya.

Dalam institusi pendidikan sekolah masing-masing perencanaan dan analisis kebutuhan tersebut disiapkan oleh bagian Perencanaan. Semua yangdibutuhkan disusun menjadi Daftar Usulan yang dimasukkan dalam Daftar Usulan kegiatan yang kemudian dikirim ke Departemen Pendidikan dan Kebudayaan.

\section{Pengadaan Sarana dan Prasarana Pendidikan}

Pengadaan merupakan segala kegiatan untuk menyediakan semua keperluan sarana dan prasarana pendidikan. Pengadaan sarana dan prasarana Pendidikan dapat dilakukan dengan cara membeli, menyewa, dan menerima hibah dari pihak lain. Pengadaan sarana dan prasarana dapat berbentuk pengadaan buku, alat, perabot dan bangunan. Sistem pengadaan sarana dan prasarana sekolah dapat dilakukan dengan berbagai cara, antara lain sebagai berikut: 
- Dropping dari pemerintah, hal ini merupakan bantuan yang diberikan pemerintah kepada sekolah. Bantuan ini sifatnya terbatas sehingga pengelola sarana dan prasarana pendidikan di sekolah tetap harus mengusahakan dengan cara lain.

- Pengadaan sarana dan prasarana sekolah dengan cara membeli, baik secara langsung maupun melalui pemesanan terlebih dahulu.

- Meminta sumbangan wali murid atau mengajukan proposal bantuan pengadaan sarana dan prasarana sekolah ke lembaga sosial yang tidak mengikat.

- Pengadaan perlengkapan dengan cara menyewa atau meminjam.

- Pengadaan perlengkapan sekolah dengan cara tukar menukar barang yang dimiliki dengan barang lain yang dibutuhkan sekolah.

\section{Penyimpanan Sarana Dan Prasarana Pendidikan}

Setelah pengadaan sarana prasarana pendidikan selanjutkan dilakukan penyimpanan sarana prasarana tersebut. Untuk menjaga keamanan sarana prasarana yang telah dibeli maka perlu disimpan dengan baik. Kegiatan penyimpanan meliputi kegiatan menerima barang, menyimpan barang dan mengeluarkan atau mendistribusikan barang-barang tersebut. Untuk keperluan penyimpanan biasanya menggunakan gudang. Untuk itu setiap petugas yang mengelola sarana dan prasarana harus memperhatikan bagaimana lokasi, ketentuan tata letak barang dan kontruksi bangunan gudang.

\section{Penginventarisasian}

Penginventarisasian adalah kegiatan melaksanakan penggunaan, penyelenggaraan, pengaturan, dan pencatatan barang-barang, menyusun daftar barang yang menjadi milik sekolah ke dalam satu daftar inventaris barang secara teratur. Tujuannya adalah untuk menjaga dan menciptakan tertib administrasi barang milik negara yang dipunyai suatu organisasi. Hal ini sesuai dengan keputusan Menteri Keuangan RI No. Kep. 225/MK/V/4/1971 (dikutip dalam Mustari, 2014) yang menyatakan bahwa barang milik negara berupa semua barang yang berasal atau dibeli dengan dana yang bersumber baik secara keseluruhan atau bagian dari Anggaran Pendapatan dan Belanja Negara (APBN) ataupun dana lainnya yang barang-barang di bawah penguasaan kantor Departemen Pendidikan dan Kebudayaan, baik yang berada di dalam maupun luar negeri. Barang/alat yang bersumber dari APBN/APBD harus dicatat dan dibukukan dalam Buku Inventaris atau Sistem Aplikasi. Barang milik negara atau menjadi milik daerah setelah melalui proses pengalihan aset dari pusat ke daerah. Kegiatan inventarisasi sarana dan prasarana pendidikan di sekolah menurut Bafadal (2003, dikutip dalam Mustari, 2014) meliputi:

- Pencatatan sarana dan prasarana sekolah dapat dilakukan di dalam buku penerimaan barang, buku bukan inventaris, buku stok barang. 
- Pembuatan kode khusus untuk perlengkapan yang tergolong barang inventaris. Caranya dengan membuat kode barang dan menempelkannya atau menuliskannya pada badan barang perlengkapan yang tergolong sebagai barang inventaris. Tujuannya adalah untuk memudahkan semua pihak dalam mengenal kembali semua perlengkapan pendidikan di sekolah baik ditinjau dari kepemilikan, penanggung jawab, maupun jenis golongannya. Biasanya kode barang itu berbentuk angka atau numerik yang menunjukkan departemen, lokasi, sekolah, dan barang.

- Semua perlengkapan pendidikan di sekolah yang tergolong barang inventaris harus dilaporkan. Laporan tersebut sering disebut dengan istilah laporan mutasi barang. Pelaporan dilakukan dalam periode tertentu, sekali dalam satu triwulan. Dalam satu tahun ajaran misalnya, pelaporan dapat dilakukan pada bulan Juli, Oktober, Januari, dan April tahun berikutnya.

\section{Penyaluran Sarana Dan Prasarana Pendidikan}

Penyaluran sarana dan prasarana pendidikan adalah suatu kegiatan yang menyangkut pendistribusian atau membagi barang sesuai kebutuhan guru atau siswa untuk keperluan kegiatan belajar mengajar. Untuk penyaluran sarana prasarana ini dilakukan atas persetujuan kepala sekolah yang mengatur bagaimana penyaluran sarana prasarana pen-didikan.

\section{Pemeliharaan Sarana Dan Prasarana Pendidikan}

Pemeliharaan adalah kegiatan merawat, memelihara, dan menyimpan barang-barang sesuai dengan bentuk-bentuk maupun jenis barangnya sehingga barang tersebut awet dan tahan lama. Pemeliharaan terhadap sarana dan prasarana pendidikan di sekolah merupakan aktivitas yang harus dijalankan untuk menjaga agar perlengkapan yang dibutuhkan oleh personel sekolah dalam kondisi siap pakai. Hal ini bertujuan untuk meningkatkan kinerja, memperpanjang usia pakai, menurunkan biaya perbaikan, dan menetapkan biaya efektif perawatan sarana dan prasarana sekolah, melestarikan kerapian dan keindahan, dan menghindarkan dari kehilangan atau setidaknya meminimalisir kehilangan. Program perawatan ini dapat ditempuh melalui langkah-langkah berikut ini:

- Membentuk tim pelaksana perawatan preventif di sekolah.

- Membuat daftar sarana dan prasarana termasuk seluruh perawatan yang ada di sekolah.

- Menyiapkan jadwal tahunan kegiatan perawatan untuk setiap perawatan dan fasilitas sekolah.

- Menyiapkan lembar evaluasi untuk menilai hasil kerja perawatan pada masing-masing bagian di sekolah.

- Memberi penghargaan bagi mereka yang berhasil meningkatkan kinerja peralatan sekolah dalam rangka meningkatkan kesadaran dalam merawat sarana dan prasarana sekolah.

Adapun program perawatan preventif di sekolah tersebut dapat dilaksanakan dengan: 
- Memberikan arahan kepada tim pelaksana perawatan preventif dan mengkaji ulang terhadap program yang telah dilaksanakan secara teratur;

- Mengupayakan pemantauan bulanan ke lokasi tempat sarana dan prasarana, untuk mengevaluasi aktivitas pelaksanaannya berdasarkan jadwal yang telah dilaksanakan;

- Menyebarkan informasi tentang program perawatan preventif untuk seluruh warga sekolah terutama guru dan siswa; dan

- Membuat program lomba perawatan terhadap sarana dan fasilitas sekolah untuk memotivasi.

Pemeliharaan sarana dan prasarana pendidikan di sekolah dapat dibedakan menjadi dua macam yaitu pemeliharaan sarana dan prasarana yang ditinjau dari sifatnya dan ditinjau dari waktunya. Jika ditinjau dari sifatnya kegiatan pemeliharaan sarana dan prasarana bersifat pengecekan, pencegahan, perbaikan ringan, dan perbaikan berat. Sedangkan ditinjau dari waktunya pemeliharaan sarana dan prasarana bersifat pemeliharaan sehari-hari (membersihkan ruang dan perlengkapannya), dan pemelihara-an berkala seperti pengecetan dinding, pemeriksaan bangku, genteng, dan perabotan lainnya.

\section{PENGELOLAAN SARANA DAN PRASARANA PENDIDIKAN YANG SEBAIKNYA DILAKUKAN DI MASA YANG AKAN DATANG UNTUK PENINGKATAN KUALITAS DAN MUTU PENDIDIKAN}

Dengan adanya pengelolaan sarana dan prasarana yang baik diharapkan dapat menciptakan sekolah yang bersih, rapi, indah, sehingga menciptakan kondisi yang menyenangkan baik bagi guru maupun untuk berada di dalam lingkungan sekolah. Tujuan dari pengelolaan sarana dan prasarana sekolah ini adalah untuk memberikan layanan secara profesional berkaitan dengan sarana dan prasarana pendidikan agar proses pembelajaran bisa berlangsung efektif. Jadi secara umum, tujuan pengelolaan sarana dan prasarana pendidikan adalah memberikan pelayanan secara professional di bidang sarana dan prasarana pendidikan dalam rangka terselenggaranya proses pendidikan secara efektif dan efisien. Secara rinci, tujuannya adalah sebagai berikut:

a. Untuk mengupayakan pengadaan sarana dan prasarana pendidikan melalui sistem perencanaan dan pengadaan yang hati-hati dan seksama. Dengan perkataan ini, melalui manajemen sarana dan prasarana Pendidikan diharapkan semua perlengkapan yang didapatkan oleh sekolah adalah sarana dan prasarana yang berkualitas tinggi, sesuai dengan kebutuhan sekolah, dan dengan dana yang efisien.

b. Untuk mengupayakan pemakaian sarana dan prasarana secara tepat dan efisien.

c. Untuk mengupayakan pemeliharaan sarana dan prasarana sekolah, sehingga keberadaannya selalu dalam kondisi siap pakai dalam setiap diperlukan oleh semua personel sekolah. Sarana dan Prasarana pendidikan, khususnya lahan, bangunan dan perlengkapan sekolah seyogyanya menggambarkan program pendidikan atau kurikulum sekolah itu. Karena bangunan dan perlengkapan sekolah tersebut diadakan 
dengan berlandaskan pada kurikulum atau program pendidikan yang berlaku, sehingga dengan adanya kesesuaian itu memungkinkan fasilitas yang ada benar-benar menunjang jalannya proses pendidikan. Pengelolaan sarana dan prasarana pendidikan adalah proses untuk menyelenggarakan dan pengawasan dalam sarana prasarana pendidikan serta dalam pengadaan sarana-sarana pendidikan yang ada di lembagalembaga pendidikan untuk mencapai tujuan tertentu. Sarana dan prasarana Pendidikan merupakan pendudkung dalam proses belajar mengajar, sehingga proses belajar mengajar dapat berjalan lancar.

\section{KESIMPULAN DAN SARAN}

\section{Kesimpulan}

Pengelolaan sarana dan prasarana pendidikan itu sangat penting untuk dikelola dengan baik. Sarana dan prasarana merupakan salah satu sumber daya pendidikan yang perlu dan sangat penting dikelola dengan baik serta merupakan bagian yang tidak dapat dipisahkan dari manajemen pendidikan. Seperti gedung, tanah, perlengkapan administrasi sampai pada sarana yang digunakan langsung dalam proses belajar mengajar di kelas. Fungsi pengelolaan sarana dan prasarana sangat mendasar sekali dalam meningkatkan kualitas pembelajaran, menciptakan iklim sosio emosional dan mengelola proses kelompok, sehingga keberhasilan guru dalam menciptakan kondisi yang memungkinkan, indikator proses belajar mengajar berlangsung secara efektif.

\section{Saran}

Sarana dan prasarana pendidikan adalah alat yang dapat membantu keberhasilan pendidikan. Untuk itu pemanfaatan dan pengelolaan serta pemeliharaannya harus lebih ditingkatkan ke arah yang lebih baik. Hendaknya pihak sekolah harus memahami bagaimana cara pengelolaan sarana dan prasarana pendidikan tersebut. Dan selalu mengambil keputusan yang cepat dalam perencanaan suatu sarana dan prasarana yang dibutuhkan oleh sebuah sekolah. Dan pihak-pihak yang bertanggung jawab terhadap pengelolaan sarana dan prasarana ini seharusnya bisa melaksanakan tugas dan tanggung jawabnya sepenuhnya.

\section{DAFTAR PUSTAKA}

Risnawati.2014.Administrasi dan Supervisi Pendidikan.Yogyakarta: Aswaja Pressindo.

Hadiwijaya,Yusuf.2012.Administrasi Pendidikan.Medan:Perdana Publishing H.M.Daryanto.2001.Administrasi Pendidikan. Jakarta: Rineke Cipta.

Peraturan Pemerinta RI No 19. 2006. Tentang Standar Nasional Pendidikan. Bandung : Fokusmedia 